\section{Relaxed restrictions blamed for rise in foot and mouth}

\section{Jim Giles, London}

Epidemiologists working on the British foot-and-mouth epidemic are blaming the relaxation of security measures for a burst of small outbreaks of the disease.

The epidemic had seemed to be under control in May (see M. Woolhouse et al. Nature 411, 258-259; 2001). The number of new cases reported each day was below five for most of June, July and August, down from a peak of more than $\mathbf{5 0}$ in April, and government officials hoped that the disease would be extinct by the end of the year.

But in Northumberland, more than 20 cases have been recorded since late August. Before that, no new cases had been reported there since May. "The tail of the disease is longer than had been hoped," says Mark Woolhouse, an epidemiologist at the University of Edinburgh.

Woolhouse points to the relaxation of restrictions on moving animals and measures to stop people carrying the virus between farms. The government had allowed some movement of animals on animal-welfare grounds. Also, farmers and vets may have stopped applying restrictions so rigorously, scientists say.

Researchers say there is a chance the disease surfacing in Northumberland was carried in sheep flocks, as sheep can carry the virus without showing any symptoms.

The government has now halted animal movements in affected areas and has imposed stricter security measures. But this is causing problems for farmers in upland areas, such as Northumberland. Animals that graze on high ground in summer are normally relocated at this time of year.

Epidemiologists say it is difficult to estimate how long the epidemic will last. The onset of winter may cause problems, they add, as the virus can survive for longer in lower temperatures.

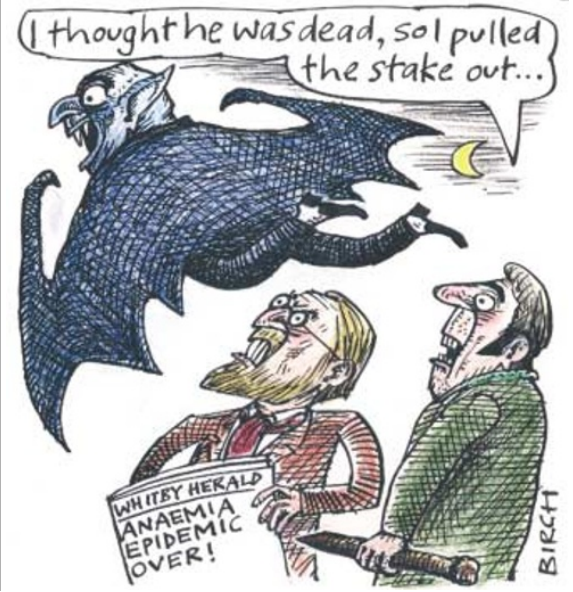

\title{
Scotland aims to capitalize on spirit of scientific innovation
}

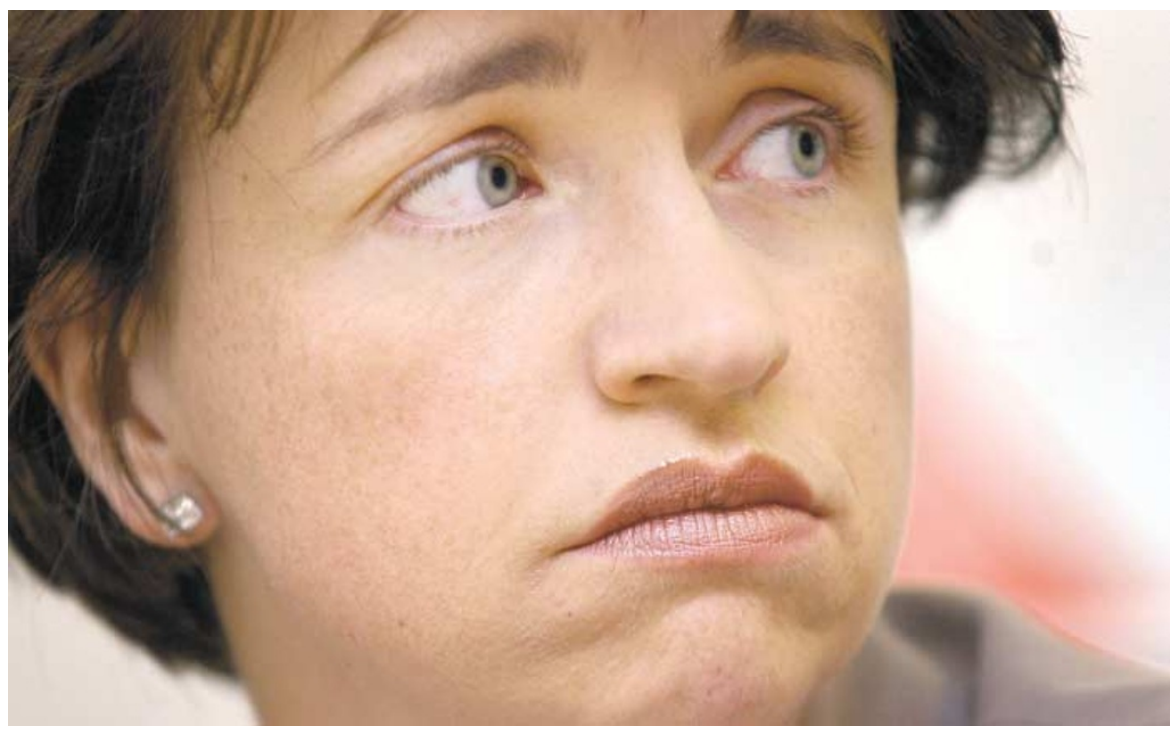

Looking to the future: Wendy Alexander seeks a smarter approach to supporting science.

\section{David Dickson, Glasgow}

Two years after re-establishing its own parliament in Edinburgh, Scotland has unveiled a science strategy aimed at bolstering innovation and increasing public understanding of science.

As part of the plan, released last month by Wendy Alexander, the Scottish Executive's minister for enterprise and lifelong learning, an advisory committee will be set up under the auspices of the Royal Society of Edinburgh (RSE) to propose research priorities and other measures for boosting Scottish science.

The strategy also pledges to enhance the teaching of science in schools, promote public understanding of science and create "a pipeline of support to carry science from Scottish laboratories into the creation of global companies".

Alexander, whose brief includes responsibility for science, said the country has a "proud history of innovation" and an "enviable international reputation in important new fields", referring to areas such as biotechnology and opto-electronics. But she added that the government "must become smarter still in the support it gives to science, the use it makes of science, and the way it explains the issues".

Her remarks reflect concerns both over Scotland's slowness to benefit from its own scientific discoveries and at the potential negative impact of public worries about breakthroughs such as the cloning of Dolly the sheep at the Roslin Institute, near Edinburgh.

Eddie Frizzell, the senior civil servant in Alexander's department, told the British Association for the Advancement of Science's meeting in Glasgow last week that "too often scientific knowledge produced in Scotland is exploited in other parts of the world". He added: "We are going to ask the advisory group at an early stage to tackle the question of where the priority areas should be."

This view was endorsed by Sir William Stewart, president of the RSE and a former chief scientific adviser to the British government. "We cannot do everything and need to focus, particularly on areas that will give this country a competitive edge," he said.

The Scottish government spends $\mathfrak{2} 220$ million (US\$320 million) on research and development each year, and Scotland obtains another $£ 165$ million a year from the British government, mainly in grants to universities from UK research councils.

The science strategy was generally welcomed by Scottish researchers, although some complain that it lacks specifics. "This is a framework rather than a route map," admits Geoffrey Boulton, professor of geophysics at the University of Edinburgh and a member of an RSE committee that influenced the strategy's recommendations.

But advocates of greater public involvement in science said the strategy is too conservative. "I am very pleased to see a science strategy for Scotland, but these things need to be given a higher priority," said Donald Bruce, a former nuclear chemist who now heads the Church of Scotland's Science, Religion and Technology Project. The document "could have been written 10 years ago", he said. "It emphasizes factors such as the need for scientists to communicate more with the public, but says very little about the need to listen to where the public is coming from." 